\title{
Pathogeographic Studies of Sugarcane Downy Mildew in TAIWAN I. Historical Analysis, Regional Pathogeographic Classification and Some Considerations of Disease Attributes of the Epidemics*
}

\author{
E. S. PoON**, L.S LEU ${ }^{* * *}$, C. $\mathrm{LIU}^{* * * *}$ and W. T. CHENG ${ }^{* * * * *}$ \\ 潘 崇儀**・呂 理榮***・劉 清****・鄭 武橴***** : 台湾に括けるサトウキビべと \\ 病の病害地理的研究 I . 過去の発生病害, 地理区域抒よび流行病に関する諸要因*
}

\begin{abstract}
The pathogeographic history of sugarcane downy mildew in Taiwan was traced from 1909 to 1978. Three major epidemic periods were distinguished: namely, 1955-57, 1965 and 1973. Geographic distribution of the disease was also mapped. Hsinying area was identified as the primary disease focus and Pingtung area, the secondary disease focus. Areas of main damage, marginal damage, sporadic attack as well as nonepidemic region were distinguished. By means of cluster analysis based on three disease attributes (disease frequency, intensity and extensity), a pathogeographic classification of the sugarcane factory districts in Taiwan was presented. The classification corresponds with the disease regions demarcated in the geographic studies. Correlation of the spatial and temporal attributes (disease intensity, extensity, frequency and duration) was found and the meaning of such correlation was discussed.
\end{abstract}

(Received July 22, 1981)

Key Words : pathogeography, Sclerospora sacchari, historical analysis, Taiwan.

\section{Introduction}

Unequal distribution of organism based on endogenic and exogenic factors is very common. Most organisms are restricted to specific areas defined by ecological boundaries. Within the total pathogen distribution area one can frequently recognize centres of high disease intensity where the pathogen develops within or close to its ecological optimum. At the edge of its area of distribution, the pathogen becomes widely dispersed and

* This work was supported in part by the National Science Council funds for research and development in science administration for 1980 and 1981.

** The senior author was affiliated with National Science Council, ROC during the course of this study. Present address : Resource Systems Institute, East-West Center, Honolulu, Hawaii, USA

*** Plant Protection Center, Taiwan, Wufeng, Taiwan, ROC

**** Department of Agronomy, Taiwan Agricultural Research Institute, Taichung, Taiwan, ROC

***** Department of Botany, National Taiwan University, Taipei, ROC 
survives only in suitable ecological niches. The following pathogeographic classification is frequently adopted to describe disease zones: (1) areas of main damage where high disease frequency, regular epidemics and heavy damage occur, (2) areas of marginal damage which are areas of fluctuation and decreasing disease severity. Epidemics occur irregularly with significant losses in some seasons only, while in others disease occurrence is insignificant, (3) areas of sporadic attack where attack or occurrence is insignificant, disease does occur, but never, or only occasionally, shows epidemic development and crosses the threshold of economic damage ${ }^{13,14}$.

Pathogeographic studies are useful in the documentation, analysis and prognosis of plant epidemics ${ }^{13}$. If geographic zones of similar disease intensity can be recognized and ecologically analyzed, long term prognosis and advance planning of control activities could become feasible. Prognosis is the prediction of disease occurrence that aims at assessing the likelihood of a given disease appearing in a certain geographic location. The pathogeographical approach to prediction of plant disease occurrence could be of worldwide, national or regional scale ${ }^{8)}$. Numerous pathogeographic studies have been conducted, some of the diseases studied are fire blight, southern corn leaf blight, Dutch elm disease, turfgrass diseases and powdery mildews ${ }^{1,3,7,12,15)}$. The objective of this paper is to conduct a historical and geographic analysis of sugarcane downy mildew in Taiwan and to present a classification of the pathogeographic regions to lay the groundwork for long term disease prediction on a regional scale.

Disease in a population must be concentrated in time or space to be called an epidemic. Spatial consideration of epidemics may refer to an increase of intensity as well as of extensity of disease. Temporal consideration includes disease duration and frequency. In the course of this study, some interesting relationships between the temporal and spatial attributes of epidemics were found, these relationships were further characterized in the hope of shedding light in the prediction of epidemics.

\section{Materials and Methods}

Historicai analysis. Disease incidence data ( of diseased farms reported) from 1909-1978 were kindly furnished by the Division of Agricultural Technology, Taiwan Sugar Corporation. Diseased farms of Taiwan Sugar Corporation or diseased contract farms reported were mapped. Similar maps of consecutive years with similar disease patterns were consolidated. Disease intensity data in terms of infection ratio of the average of 21 districts of sugar factories from 1955-1978 were calculated.

Geographic studies. Disease data (combined data of contract farms and farms of Taiwan Sugar Corporation) from 1965-1978 were used. Infection ratio for each sugar factory district was calculated from either disease acreage or the number of diseased plants since the former which is an indicator of disease extensity may be an overestimate whereas the latter of disease intensity may be an underestimate. An average of the two values was taken. Normalized indicator of the infection ratio for each sugar factory district was calculated. Disease intensity (in terms of normalized indicator) was mapped.

Pathogeographic classification. Based on three disease attributes (disease intensity, extensity, frequency) exhibited during the period of 1964-1978, the 21 diseased sugar factory districts were calssified into different pathogeographic regions by means of 


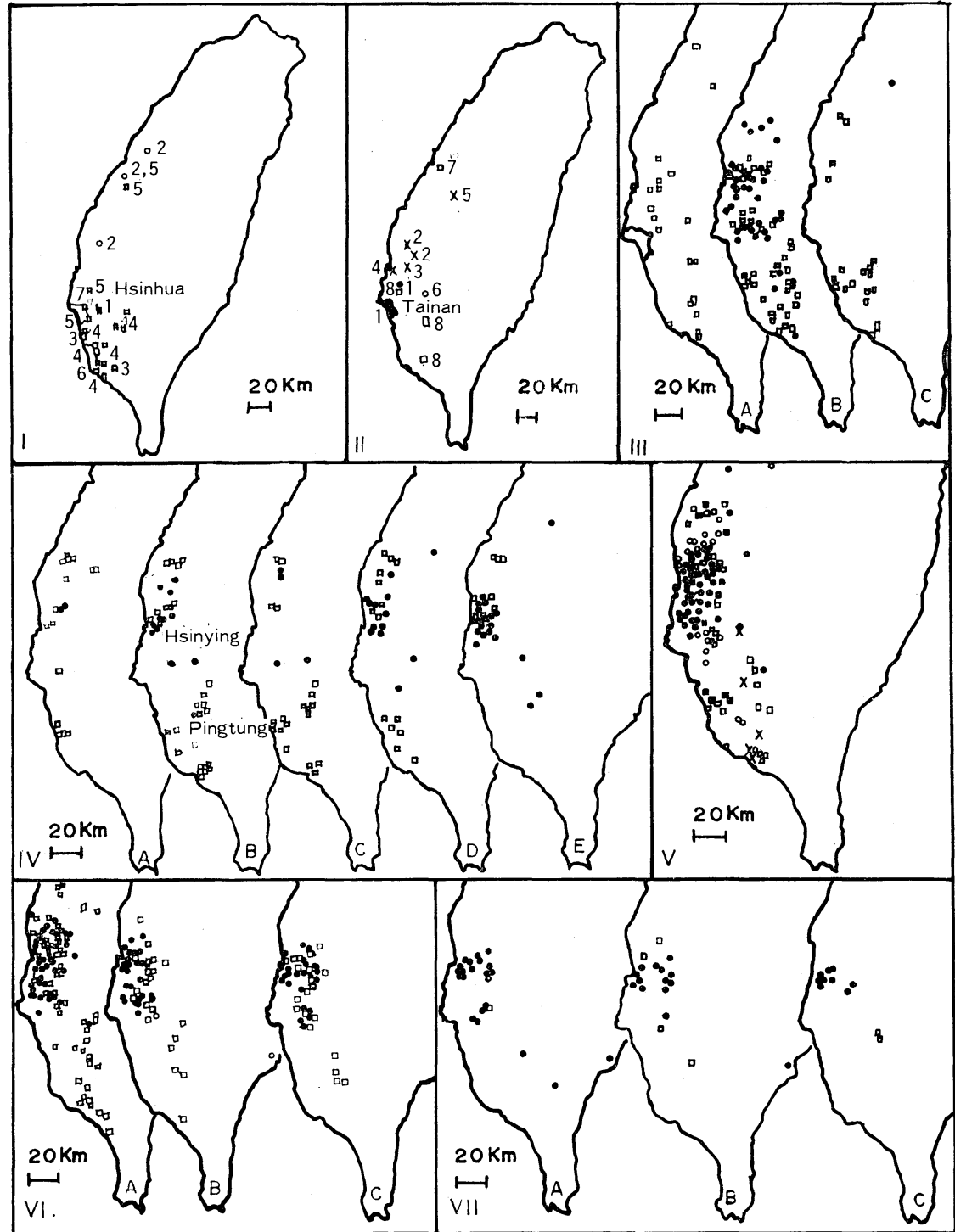

Fig. 1. Disease spread of sugarcane downy mildew in Taiwan from 1909-1978.

I. 1909-1946: 1, origin of sugarcane downy mildew in Taiwan; $\bigcirc 2$, disease occurred in the area during 1910-1911; $\square 3,1912$ 1913 ; 4, 1916-1933 ; 5, 1933-1934; 6, $1944 ; 7,1946$.

II. 1947-1953: 1, disease occurred in these areas every year from 1947$1953 ; \times 2$, disease occurred in these areas only during 1950 $1953 ; 3,1947,1949$ and $1952 ; 4,1948,1950$ and $1951 ; 5,1950$ $1952 ; \bigcirc 6,1948 ; \square 7,1952 ; 8,1953$.

III. 1954-1959 : A, diseased locations, 1954 ; B, 1955-1957 ; C, 1959.

IV. 1960-1964: A, 1960, B. 1961 ; C, 1962 ; D, 1963 ; E, 1964.

V. 1965-1968: disease occurred in these areas every year from 1965-1968; $\times$ disease occurred in both 1966 and 1967; $\square$ disease occurred only in one of the following year: 1966, 1967 or 1968. Circles denote contract farms, squares denote corporation farms,

VI. 1969-1975 : A, 1969-1973 ; B, 1974 : C, 1975.

VII. 1976-1978: A, 1976; B, 1977: C, 1978. III B and C, IV, VI and VII : denotes contract farms. $\square$ denotes corporation farms. 
cluster analysis based on Gower's coefficient. Pooled data of contract farms and Taiwan Sugar Corporation farms were analyzed.

Correlation analysis. Correlation coefficients of the 9 disease attributes (disease intensity, extensity, frequency, number of alternations of diseased and nondiseased years, longest nondiseased period, first appearance of the first epidemics, first appearance of the second epidemics, duration index which is a combination of the four preceding attributes and longest diseased period) were calculated. Three sets of data (Taiwan Sugar Corporation farms, contract farms and the sum of the two) were used.

\section{Results}

\section{Historical analysis}

The disease history from 1909-1978 was divided into 7 eras (Fig. 1). I. 1909-1946: The origin of disease was found in Hsinhua in 1909 and sporadic disease incidences were reported in Taichung and southern Taiwan. II. 1947-1953: Disease occurred in Tainan areas every year. This was a disease focus on a macroscale. Disease occurred in some of the years in areas nearby the focus, sporadic disease incidences were reported further away from the disease focus. III. 1954-1959: The first epidemic occurred in 1955-1957 (Since data for 1955-1957 were 3-year consolidated data, the exact epidemic year cannot be identified.). Diseased farms were found on the western part of the island only. IV. 1960-1964: Disease was found sparsely and sporadically, but there seemed to be two disease foci, one in Hsinying area, the other in Pingtung. V. 1965-1968: The second epidemic occurred in this period. A disease focus was found in Hsinying area. VI. 1969-1975: Disease intensity declined, disease was reported for the first time in the eastern part of the island. However the disease focus of Hsinying remained, but that

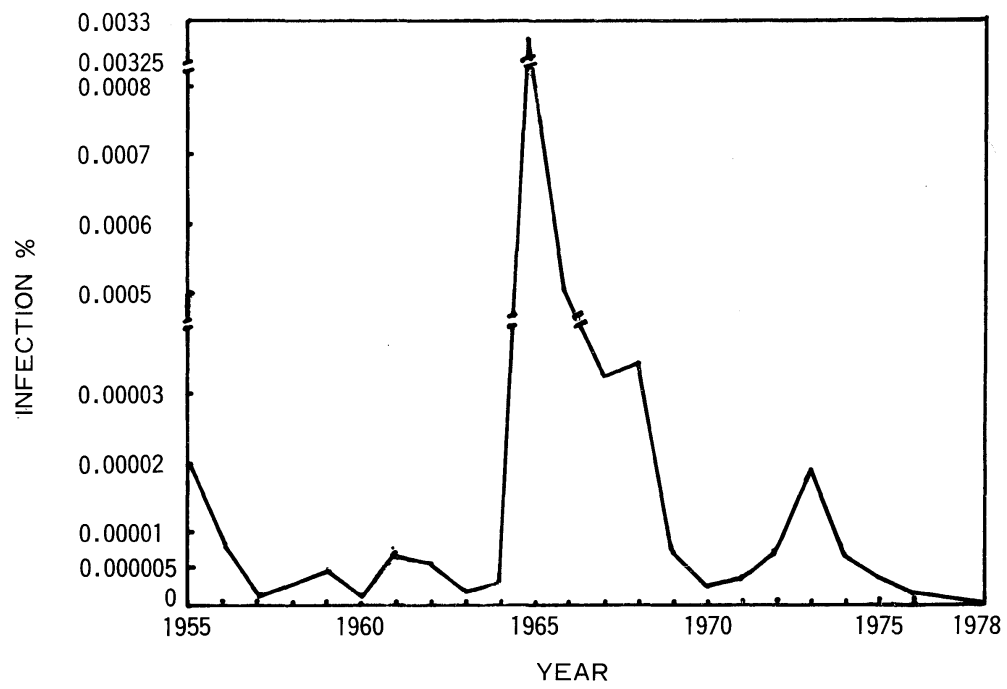

Fig. 2. Dynamics of sugarcane downy mildew occurrence in Taiwan from 1955-1978. (Infection ratio $=$ total diseased acreage in all sugar facotry districts/ total sugarcane planting acreage in all districts). 
of Pingtung, gradually disappeared after 1975. VII. 1976-1978 : Disease incidences were sparse, however the Hsinying disease focus remained. Figure 2 shows the disease intensity of the sugar factory districts from 1955-1978. 1955, 1965 and 1973 can be identified as peak epidemic years.

\section{Disease distribution}

The disease intensity map (Fig. 3) indicates Hsinying area to be the primary disease focus and the area of main damage, region surrounding the focus and Pingtung area are areas of marginal damage. Areas of sporadic attack include areas north and south of the areas of marginal damage (Kaoshiung and Yunlin areas, Taitung). Nonepidemic regions are found in Taichung and Hualien area.

\section{Pathogeographic classification}

Figure 4 shows a pathogeographic classification of the 21 diseased sugar factory districts. The disease distribution pattern corresponds with the pathogeographic classification based on cluster analysis.

\section{Correlation analysis}

There appears to be some relationship among the 4 disease attributes; disease intensity, extensity, frequency and duration (Fig. 5). Positive correlations were found with disease intensity, extensity, frequency and longest diseased period in the analysis

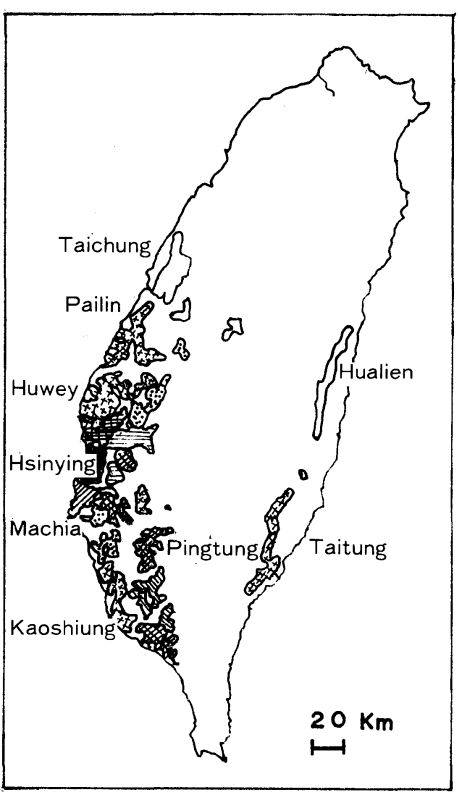

Fig. 3. Disease distribution map of sugarcane downy mildew in Taiwan from 1965-1978. Region of main damage: normalized indicator value above 3.0 , Region of marginal damage: normalized indicator value $1.1-3.0$ 曲, 0.1-1.0目, 0--0.2 四, - 0.21$-0.3 \mathbb{N},-0.3-0.4 \mathbb{Z}$.

Region of sporadic attack: $-0.41--0.4 \bigotimes_{\text {, }}$, below -0.5 $\therefore$. Nonepidemic region : $\square$. of all three sets of data. The correlation coefficients of the four factors for the combined data of Taiwan Sugar Corporation and contract farms are shown in Table 1. Good correlation was found with duration index and other disease attributes. Correlation of the other attributes was fair, but showing no distinct pattern in all three sets of data.

\section{Discussion}

From 1909-1946, the disease occurred in different locations at random. The general pattern corresponds with that reported in literature ${ }^{5,6)}$. In 1947-1953, a disease focus began to develop. No severe epidemics occurred in this period because rogueing practice was effective ${ }^{4)}$. The epidemic occurring in 1955 was mainly due to planting of F 134 and PT 43-52 and corn interplanting ${ }^{2)}$. The second epidemic that occurred in 1965 was also attributed to the planting of susceptible varieties and corn interplanting ${ }^{2)}$. Disease was under control after the restriction on corn interplanting had been enforced. The third epidemic occurring in 1973 has not been accounted for in literature, it can probably 


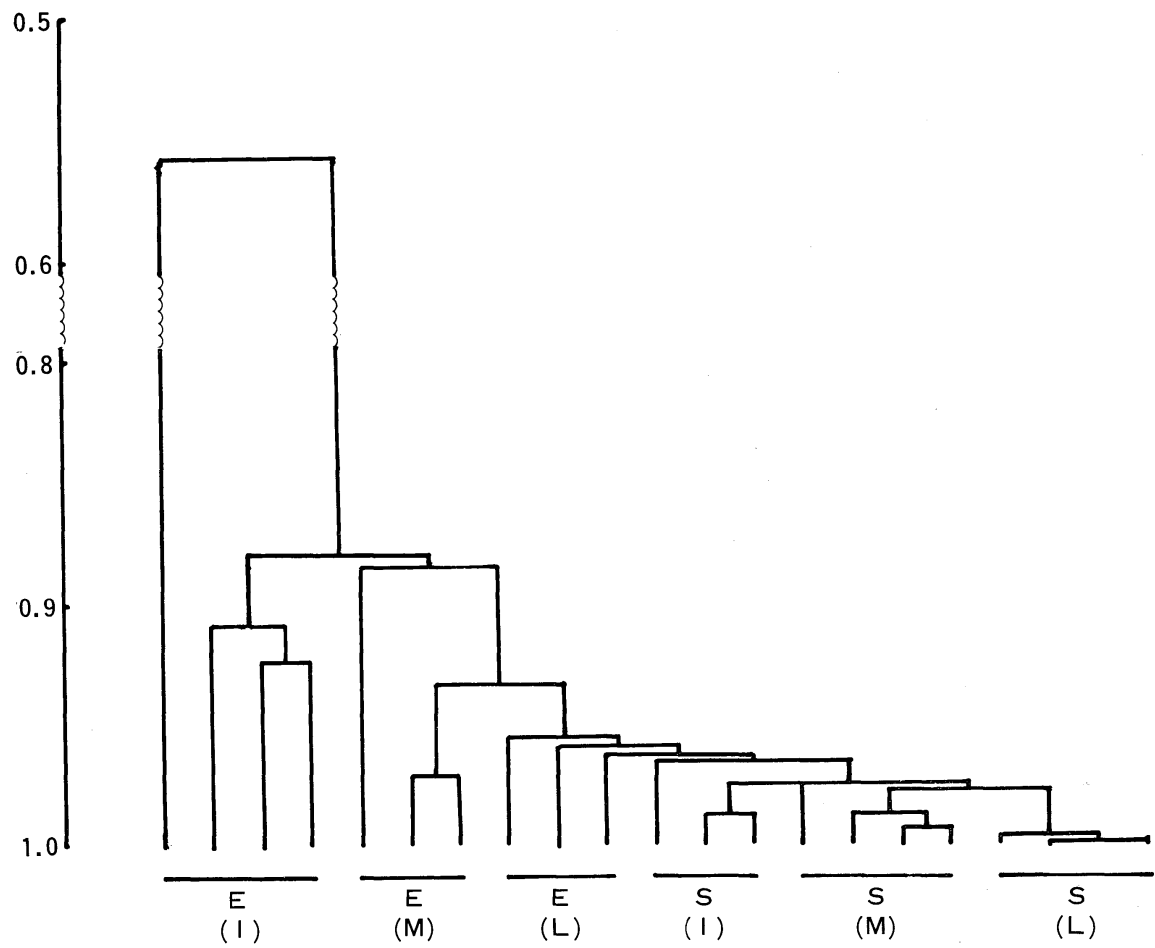

Fig. 4. Pathogeographic classification of diseased sugar factory districts E, epidemic; I, intense; M, moderate; L, light. Region of main damage, $E(I)$ : region of marginal damage, $E(M)$ and $E(L)$ : region of sporadic attack, S (I), S (M) and S(L).

Table 1. Correlation coefficients of disease intensity, extensity, frequency and longest diseased period reported in the sugarcane downy mildew disease epidemics in Taiwan

\begin{tabular}{lccc}
\hline Characters & Extensity & Frequency & $\begin{array}{c}\text { Longest diseased } \\
\text { period }\end{array}$ \\
\hline Intensity & $0.899^{* * *}$ & $0.885^{* * *}$ & $0.664^{* * *}$ \\
Extensity & & $0.947^{* * *}$ & $0.758^{* * *}$ \\
Erequency & & & $0.796^{* * *}$ \\
\hline
\end{tabular}

*** significant at 0.001 level

be attributed to the planting of susceptible vaireties. Both the historical and geographic studies indicate that there were two disease foci, Hsinying area being the primary focus due to corn interplanting while Pingtung was the secondary focus probably due to the favorable environmental conditions.

The qualitative and quantitative classifications of pathogeographic regions reported in this paper are highly subjective in many respects, however both show similar patterns. The use of these classifications in disease prognosis is premature. It is the intention of the authors to characterize the different regions and to identify the cause for the exhibition 


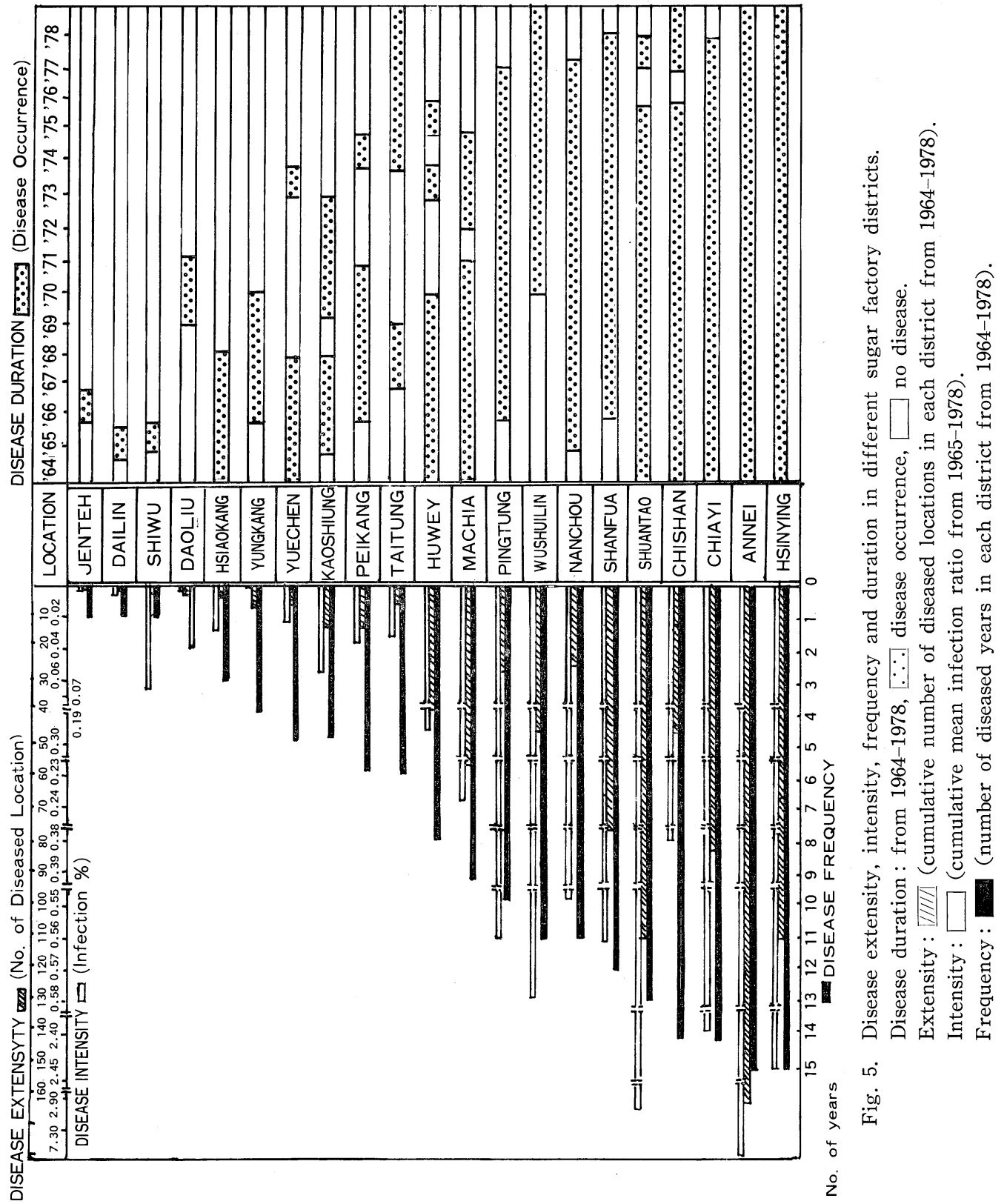


of certain disease intensities in certain regions so that proper planting strategy and control measures can be adopted to minimize disease incidence. Studies on the host and climatic attributes of the different regions are presented in other papers ${ }^{8,9,10)}$.

No conclusion can be reached on whether the interesting correlations found with the four disease attributes, disease intensity, extensity, frequency and duration are meaningful or not. The phenomenon may or may not be common to all diseases. It is speculated that for a simple interest disease, correlation among the four attributes may or may not exist, but it would not be surprising to find such correlation in most compound interest diseases*. In soil-borne disease or insect transmitted diseases where disease dispersal may be random, disease intensity may or may not correlate with disease extensity. Also disease duration may or may not correlate with disease intensity, depending on the survival ability of the pathogen. It would be necessary to conduct field experiments to compare simple and compound interest diseases in terms of their disease attributes to elucidate the meaning of the correlations. Such correlations may have predictive values useful in the formulation of planting strategies and designing appropriate control measuers.

The authors wish to thank Dr. W.H. Hsieh, Sugar Research Institute, for his generous assistance and Dr. H.P. Wu, Institute of Botany, Academia Sinica, for his advice in the course of this study. Thanks are also due to the Department of Agricultural Extension, Sugar Research Institute, for drawing the map of contract farms and the Division of Agricultural Technology, Taiwan Sugar Corporation, for providing the requisite data on sugarcane.

\section{Literature cited}

1. Brasier, C. M. (1979). Nature $281: 78-80$.

2. Chu, H. T. (1968). Proc. Int. Soc. Sugarcane Tech. 13: 1180-1190.

3. Haygood, R. A. and Spencer, J. A. (1979). Plant Dis. Reptr. 63: 852-855.

4. Law, G. S. (1951). Sugar News 8 (4): 1-5 (in Chinese).

5. Miyake, T. (1912). Taiwan Sugar Industry Special Report 1, 61 pp.

6. Miyake, T. (1927). Proc. Int. Soc. Sugarcane Tech. 2: 114-115.

7. Moore W. F. (1970). Plant Dis. Reptr. $54: 1104-1108$.

8. Poon, E. S., Leu, L. S. and Liu, C. (1982). Ann. Phytopath. Soc. Japan 48: 162-168.

9. Poon, E. S., Leu, L. S. and Liu, C. (1982). Plant Protection Bulletin (Taiwan) 24 : (in press).

10. Poon, E. S., Leu, L. S. and Liu, C. (1982). Ibid. 24 : (in press).

11. Reichert, I. and Palti, J. (1967). Mycopathol. Mycol. Appl. 32: 337-355.

12. Van der Zwet, T. (1968). Plant Dis. Reptr. 52: 698-702.

13. Weltzien, H. C. (1972). Ann. Rev. Phytopathol. 10: 277-298.

14. Weltzien, H. C. (1978). In Plant Disease: an advanced treatise Vol. II. (Horsfall, J. G. \& Cowling, E. B., eds) Academic Press, N. Y. p. 339-360.

15. Weltzien, H. C. (1978). In The Powdery Mildews (Spencer, D. M., ed.) Academic Press, London. p. 39-49.

16. Zadoks, J. and Schein, R. D. (1979). Epidemiology and Plant Disease Management. Oxford press, London. 427 pp.

* The sugarcane downy mildew disease is considered as a compound interest in this case. 
和 文 摘 要

台湾に括けるサトウキビベと病の病害地理的研究

I . 過去の発生病害, 地理区域および流行病に関する諸要因

潘 崇儀・呂 理蔡・劉 清・鄭 武嫩

1909年から1978年までの台湾に和けるサトウキビベと病の病害地理区域の記録を分析した結果，三回の流 行病年代を認めた。すなわち1955～57，1965抌よび1973であった。病害地理区域を図で示した。新営地域は 第一回の病害発生の中心で屏東地域が第二回の中心である。病害地理区域は主要被害地区，周辺被害地区， 偶発地区および非流行地区に区別することができる。クラスター分析法 (Cluster analysis) で発病頻度，発 病強度扣よび発病範团などの発病要因にもとづき，台海に拈ける製糖工場別の発病地域を明らかにした。こ の分類法は地域的発病区域の分析と一致する。空間的分布と一時的要因（たとえば病害の強度, 範囲, 頻度 ならびに持続性）と関係があることについては本文で検討した。 